\title{
Efektivitas Model Berpikir Berbicara Menulis dengan Media Foto Jurnalistik dalam Pembelajaran Menulis Puisi pada Siswa Kelas VIII SMP
}

\author{
Juwanda $^{\text {() }}$, Nita Erlina ${ }^{2)}$ \\ juwandacrb165@gmail.com ${ }^{1)}$, nitaerlina1414@gmail.com ${ }^{2)}$ \\ Program Studi Pendidikan Bahasa dan Sastra Indonesia, Universitas Swadaya Gunung Jati \\ Jalan Perjuangan No 1 Kota Cirebon, Indonesia
}

\begin{abstract}
Abstrak. Tujuan penelitian ini adalah untuk mendeskripsikan efektivitas model Berpikir Berbicara Menulis dengan media foto jurnalistik dalam pembelajaran menulis puisi. Metode penelitian yang digunakan adalah metode eksperimen semu (quasi experimental design) dengan menggunakan desain penelitian yaitu nonequivalent control group design, teknik pengumpulan data yang digunakan berupa tes dan observasi. Teknik pengolahan data menggunakan uji statistik yaitu uji $t$ dan deskripsi. Populasi dalam penelitian ini yaitu seluruh siswa kelas VIII SMP Negeri 9 Cirebon dan sampel yang digunakan adalah kelas VIII F sebagai kelas eksperimen dan kelas VIII G sebagai kelas kontrol dengan jumlah siswa pada masing-masing kelas sebanyak 30 siswa. Dalam penelitian ini diperoleh hasil berupa 1) efektivitas model Berpikir Berbica Menulis dengan media foto jurnalistik dalam pembelajaran menulis puisi, 2) aktivitas siswa dalam pembelajaran menulis puisi menggunakan model Berpikir Berbicara Menulis dengan media foto jurnalistik, dan 3) profil tulisan siswa dalam pembelajaran menulis puisi menggunakan model Berpikir Berbicara Menulis dengan media foto jurnalistik. Hal tersebut dapat dibuktikan dengan adanya peningkatan keterampilan menulis puisi siswa pada tes awal dan tes akhir setelah menerapkan model Berpikir Berbicara Menulis dengan media foto jurnalistik. Tes awal nilai rata-rata sebesar 35, dan tes akhir nilai rata-rata sebesar 79,1. Hal ini menunjukan peningkatan dari tes awal ke tes akhir sebesar 44,1. Dengan demikian dapat dinyatakan bahwa model Berpikir Berbicara Menulis dengan media foto jurnalistik dalam pembelajaran menulis puisi efektif.
\end{abstract}

Kata kunci: model berpikir berbicara menulis, foto jurnalistik, puisi

\section{Pendahuluan}

Keterampilan menulis merupakan keterampilan yang memiliki tingkat kesulitan cukup tinggi dibandingkan dengan keterampilan berbahasa yang lainnya. Hal tersebut karena keterampilan menulis membutuhkan pengetahuan, pemikiran, dan penguasaan yang luas, baik dari segi menuangkan ide, isi, gagasan, pemikiran, dan juga segala unsur kebahasaannya. Namun demikian, menulis sama seperti keterampilan berbahasa yang lain, yang akan dikuasai apabila giat berlatih. Latihan yang terus menerus dan konsisten akan dapat membuat seseorang terampil dalam menulis. Oleh karena itu, salah satu cara meningkatkan keterampilan menulis seseorang adalah dengan mempelajarinya di ranah formal yaitu sekolah.

Untuk meningkatkan keterampilan menulis, siswa sudah harus dilatih menulis sejak di sekolah dasar (SD). Pengembangan kompetensi lulusan bahasa Indonesia ditekankan pada kemampuan mendengarkan, berbicara, membaca, dan menulis. Pengembangan tersebut 
dilakukan melalui media teks. Sehingga siswa dituntut mampu menulis sebuah teks. Di dalam K-13 terdapat sebuah kompetensi yang menuntut siswa mampu menulis sebuah teks sesuai dengan struktur dan kaidah kebahasaannya. Salah satu teks dalam kurikulum tersebut adalah puisi. Kompetensi tersebut dapat ditemui pada siswa kelas VIII dengan Kompetensi Dasar (KD) 4.8 yaitu menyajikan gagasan, perasaan, pendapat dalam bentuk teks puisi secara tulisan/lisan dengan memperhatikan unsur pembangun puisi.

Berdasarkan studi pendahuluan ditemukan beberapa faktor penghambat yang dialami siswa kelas VIII SMP Negeri 9 Cirebon yaitu 1) kurangnya partisipasi siswa dalam pembelajaran bahasa Indonesia khususnya menulis puisi, 2) siswa sering mengalami kesulitan dalam menemukan ide dalam menulis puisi, 3) kurangnya motivasi siswa dalam pembelajaran menulis puisi karena masih belum sesuainya model atau media pembelajaran yang digunakan dengan karakteristik materi yang diajarkan, 4) siswa masih sulit menemukan atau menuangkan ide ketika tema dalam menulis puisi ditentukan oleh guru, dan 5) siswa belum mampu menyusun kata-kata sehingga dapat menjadi sebuah puisi yang indah dan cenderung masih banyak menggunakan kata-kata lugas dan belum menggunakan majas atau gaya bahasa dalam puisinya.

Dari permasalahan di atas, guru harus membuat sebuah inovasi dengan menerapkan strategi atau model pembelajaran yang dapat meningkatkan motivasi siswa. Banyak modelmodel yang inovatif dalam pembelajaran. Salah satu model yang sesuai dengan karakteristik materi ajar khususnya puisi adalah model Berpikir Berbicara Menulis.

Pembelajaran menulis puisi membutuhkan sebuah teknik ataupun model yang tepat yang nantinya akan mampu merangsang ide-ide serta gagasan siswa dalam menulis puisi. Kegiatan pembelajaran berfokus agar siswa dapat mencapai kemampuan menulis puisi dengan baik. Peran guru dalam pembelajaran yaitu sebagai fasilitator yang dapat diwujudkan dengan cara membimbing siswa berlatih menulis puisi. Siswa nantinya dapat dengan bebas berekspresi menuangkan idenya dari hasil berpikir (think). Siswa dapat berkolaborasi dengan saling berbicara (talk) dengan siswa lain dalam forum diskusi kelompok. Kemudian siswa dapat menuliskan (write) ide atau gagasan ke dalam sebuah tulisan dengan menggunakan diksi, kosa kata, atau majas yang sesuai.

Berdasarkan penjelasan di atas penulis akan melakukan penelitian dengan judul Efektivitas Model Berpikir Berbicara Menulis dengan Media Foto Jurnalistik dalam Pembelajaran Menulis Puisi pada Siswa Kelas VIII SMP Negeri 9 Cirebon.

Dalam penelitian ini, penulis merumuskan masalah penelitian sebagai berikut. (1) Apakah penggunaan model Berpikir Berbicara Menulis dengan media foto jurnalistik dalam pembelajaran menulis puisi pada siswa kelas VIII SMP Negeri 9 Cirebon efektif? (2) Bagaimana aktivitas siswa kelas VIII SMP Negeri 9 Cirebon dalam pembelajaran menulis puisi menggunakan model Berpikir Berbicara Menulis dengan media foto jurnalistik? (3) Bagaimana profil teks puisi hasil tulisan siswa kelas VIII SMP Negeri 9 Cirebon dalam pembelajaran menulis puisi menggunakan model Berpikir Berbicara Menulis (Think-TalkWrite) dengan media foto jurnalistik?

Berdasarkan rumusan masalah di atas, penulis merumuskan tujuan penelitian ini untuk: (1) menjelaskan efektivitas model Berpikir Berbicara Menulis dengan media foto jurnalistik dalam pembelajaran menulis puisi pada siswa kelas VIII SMP Negeri 9 Cirebon, (2) mendeskripsikan aktivitas siswa kelas VIII SMP Negeri 9 Cirebon dalam pembelajaran 
menulis puisi menggunakan model Berpikir Berbicara Menulis dengan media foto jurnalistik, dan (3) mendeskripsikan profil tulisan siswa kelas VIII SMP Negeri 9 Cirebon dalam pembelajaran menulis puisi menggunakan model Berpikir Berbicara Menulis dengan media foto jurnalistik.

\section{Metode}

Metode penelitian adalah sebuah metode untuk mengumpulkan data yang digunakan peneliti untuk melakukan penelitian. Sugiyono (2017) menjelaskan bahwa metode penelitian pada dasarnya merupakan cara ilmiah untuk mendapatkan data dengan tujuan dan kegunaan tertentu. Sehingga dapat diartikan bahwa metode penelitian adalah kegitan penelitian untuk mendapatkan data yang benar yang memiliki kevalidan dan penelitian tersebut memilki tujuan dan kegunaannya tertentu.

Berdasarkan penjelasan tersebut, peneliti menggunakan metode eksperimen semu (Quasi Experimental Design) untuk melihat perlakuan di dalam proses pembelajaran terhadap hasil belajar siswa. Sugiyono (2017) menjelaskan bahwa desain ini mempunyai kelompok kontrol, tetapi tidak dapat berfungsi sepenuhnya untuk mengontrol variabelvariabel luar yang mempengaruhi pelaksanaan eksperimen. Pada penelitian yang penulis lakukan, penulis akan menngunakan dua kelas, yaitu kelas eksperimen dan kelas kontrol.

Populasi dalam penelitian ini adalah seluruh siswa kelas VIII SMP Negeri 9 Cirebon yang berjumlah sembilan kelas yaitu kelas VIII A - VIII I dengan jumlah siswa sebanyak 270 siswa. Sampel yang digunakan dalam penelitian ini adalah kelas VIII F sebagai kelas eksperimen dan kelas VIII G sebagai kelas kontrol. Dalam penelitian ini teknik pengambilan sampel yang digunakan oleh peneliti adalah teknik pengambilan sampel dengan pertimbangan tertentu (sampling purposive).

Teknik pengumpulan data adalah teknik yang digunakan peneliti untuk mengumpulkan data. Teknik pengumpulan data yang akan digunakan penulis dalam penelitian ini adalah teknik observasi dan teknik tes. Kedua teknik ini digunakan penulis untuk mengetahui kemampuan siswa dalam pembelajaran menulis puisi sesuai dengan indikator pencapaian. Teknik observasi digunakan untuk mengetahui aktivitas siswa selama proses pembelajaran, sedangkan teknik tes digunakan untuk mengukur kemampuan siswa dalam menulis atau memproduksi puisi.

\section{Hasil dan Pembahasan}

Berdasarkan hasil observasi bahwa secara keseluruhan aktivitas siswa pada saat proses pembelajaran sudah sangat baik, walaupun masih terdapat kekurangan pada beberapa aspek. Data hasil aktivitas siswa dalam pembelajaran menulis puisi dari tiap aspek yang dinilai adalah sebagai berikut. Siswa menyimak penjelasan guru mengenai kompetensi dasar yang akan dicapai, menyampaikan cakupan materi dan penjelasan uraian kegiatan sesuai silabus mendapat nilai $100 \%$ dan termasuk ke dalam kategori sangat baik. Pada aspek siswa mengamati contoh teks puisi yang dibagikan guru mendapat nilai $100 \%$ dan termasuk ke dalam kategori sangat baik. Aspek Siswa bersama dengan guru menelaah contoh teks puisi mendapat nilai 90\% termasuk ke dalam kategori sangat baik. Aspek Siswa bertanya jawab dengan guru mengenai materi yang telah diajarkan mendapat nilai $70 \%$ termasuk ke dalam kategori baik. 
Pada aspek siswa menyimak dengan cermat penjelasan guru mengenai tugas yang harus dikerjakan mendapat nilai 100\% dengan kategori sangat baik. Aspek siswa mengamati dengan cermat objek yang ada pada foto yang telah dibagikan guru mendapat nilai $100 \%$ dengan kategori sangat baik. Aspek siswa membentuk kelompok yang terdiri atas 5 orang berdasarkan instruksi guru mendapat nilai $100 \%$ dengan kategori sangat baik. Pada aspek siswa berdiskusi dan saling bertukar informasi tentang hasil catatannya mengenai objek yang ada dalam foto yang dibagikan guru mendapat nilai 76,7\% dengan kategori baik. Aspek siswa bersama dengan guru menyimpulkan hasil diskusi yang telah dilakukan mendapat nilai 93\% dengan kategori sangat baik. Pada aspek siswa secara individu mengembangkan ide yang mereka dapat dari hasil diskusi mengenai objek yang ada dalam foto menjadi sebuah puisi juga mendapat nilai $100 \%$ dan dengan kategori sangat baik.

Berdasarkan analisis yang dilakukan penulis pada kelas eksperimen, profil siswa sudah terlihat cukup bagus. Hal ini dapat dilihat dari hasil terendah yang diperoleh siswa dan keberhasilan siswa memperoleh nilai tertinggi untuk mencapai indikator yang harus dicapai selama kegiatan pembelajaran. Dengan kata lain siswa telah mampu menyerap apa yang telah mereka pelajari. Sehingga peneliti dapat menyatakan bahwa model Berpikir Berbicara Menulis (Think Talk Write) dengan media foto jurnalistik dapat meningkatkan kemampuan siswa dalam menulis puisi.

Berdasarkan hasil uji-t nilai akhir kelas eksperimen dan kelas kontrol diperoleh nilai $\mathrm{t}_{\text {hitung }} 4,858$ dengan derajat keberhasilan (df) $(\mathrm{n} 1+\mathrm{n} 2-2)=60-2=58$, diperoleh $\mathrm{t}_{\text {tabel }}=2,042$. Dengan $\alpha=5 \%$ atau 0,05 dan diperoleh nilai Sig. (2-tailed) 0,000 $<0,05$. Sesuai dengan pengambilan keputusan dalam uji-t dua sampel yang saling bebas, maka $\mathrm{H}_{0}$ ditolak dan $\mathrm{H}_{1}$ diterima.

Artinya, terdapat perbedaan hasil belajar siswa pada pembelajaran menulis puisi menggunakan model Berpikir Berbicara Menulis dengan media foto jurnalistik pada kelas VIII SMP Negeri 9 Cirebon. Dengan kata lain, penerapan model Berpikir Berbicara Menulis dengan media foto jurnalistik lebih efektif dibandingkan dengan pembelajaran yang tidak menggunakan model tersebut.

\section{Simpulan}

Berdasarkan hasil penelitian yang telah dilakukan penulis di SMP Negeri 9 Cirebon dengan judul "Efektivitas Model Berpikir Berbicara Menulis dengan Media Foto Jurnalistik dalam Pembelajaran Menulis Puisi pada Siswa Kelas VIII SMP Negeri 9 Cirebon” dapat disimpulkan sebagai berikut.

1. Model pembelajaran Berpikir Berbicara Menulis dengan media foto jurnalistik dalam pembelajaran menulis puisi pada siswa kelas VIII SMP Negeri 9 Cirebon efekti. Hal ini ditunjukan melalui hasil tes awal kelas eksperimen dengan jumlah nilai 1050 dengan nilai rata-rata 35 dan jumlah nilai tes akhir 2374 dengan nilai rata-rata 79,1. Sedangkan hasil tes awal siswa kelas kontrol diperoleh jumlah nilai 1142 dengan nilai rata-rata 38,1 dan jumlah nilai tes akhir 2118 dengan nilai rata-rata 70,6. Nilai tes akhir pembelajaran menulis puisi di kelas eksperimen lebih baik dibandingkan dengan kelas kontrol. Selain itu, hasil perhitungan uji-t juga membuktikan bahwa $t_{\text {hitung }}>\mathrm{t}_{\text {tabel }}$ atau 4,858 $>2,042$ pada taraf signifikansi $5 \%$. Hal ini berarti $\mathrm{H}_{0}$ ditolak dan $\mathrm{H}_{1}$ diterima. 
2. Berdasarkan hasil pengamatan yang dilakukan selama proses pembelajara melalui observasi, dapat dikatakan bahwa penerapan model Berpikir Berbicara Menulis dengan media foto jurnalistik dalam pembelajaran menulis puisi dapat membuat siswa lebih aktif di kelas. Keaktifan tesebut terlihat dengan aktivitas siswa yang bersemangat, lebih kreatif, dapat memecahkan masalah dengan cepat, lebih kritis dalam berpikir sehingga siswa lebih banyak bertanya hal-hal yang mereka kurang pahami, lebih berani dalam menjawab pertanyaan-pertanyaan yang berikan guru, lebih aktif dalam kegiatan diskusi kelompok, serta dapat mempermudah siswa menuangkan ide atau gagasan mereka ke dalam sebuah tulisan. Hal tersebut terbukti dari hasil deskripsi lembar pedoman observasi yang dapat dihitung secara keseluruhan dengan jumlah perhitungan persentase keaktifan siswa diperoleh hasil sebanyak 93,6\% dan berada pada kategori sangat baik.

3. Pada analisis tulisan siswa kelas VIII SMP Negeri 9 Cirebon dalam pembelajaran menulis puisi yaitu dilihat dari segi kesesuaian isi dengan tema secara keseluruhan siswa sudah mampu menulis puisi sesuai dengan tema yang ditentukan mencapai $100 \%$ dengan kategori sangat baik; ketepatan dalam pemilihan kata (diksi) mencapai $100 \%$ dengan kategori sangat baik; ketepatan menggunakan imaji terhadap objek mencapai $100 \%$ dengan kategori sangat baik; dan kemampuan menggunakan gaya bahasa (majas) dapat dikatakan sudah cukup baik mencapai $90 \%$. Hal tersebut terlihat pada hasil tulisan siswa pada tes akhir di kelas eksperimen yang sudah cukup memenuhi keriteria penilaian yaitu diperoleh jumlah tes akhir sebesar 2374 dengan nilai rata-rata 79,1.

\section{Daftar Pustaka}

Aminuddin. (2015). Pengantar Apresiasi Karya Sastra. Bandung: Sinar Baru Algesindo.

Arsyad, A. (2013). Media Pembelajaran. Jakarta: Raja Grafindo Persada.

Cakiban. (2016). Jurnal. Peningkatan Kemampuan Siswa Menulis Teks Berita Melalui Strategi "TTW" dengan Media Foto Jurnalistik. Pemalang: Jurnal Penelitian Pendidikan Indonesia.

Dalma. (2014). Keterampilan Menulis. Jakarta: Raja Grafindo Persada.

Daryanto. (2012). Media Pembelajaran. Bandung: PT Sarana Tutorial Narani Sejatera.

Gani, E. (2014). Kiat Membaca Puisi: Teori dan Terapan. Bandung: Pustaka Reka Cipta.

Hamdani. (2011). Strategi Belajar Mengajar. Bandung: Pustaka Setia.

Hamdayana, J. (2014). Model dan Metode Pembelajaran Kreatif dan Berkarakter. Bogor: Ghalia Indonesia.

Hidayati, L. (2012). Menumbukan Karakter Positif dengan Menulis Puisi. Yogyakarta: Fire Publisher.

Huda, M. (2017). Model-Model Pengajaran dan Pembelajaran. Yogyakarta: Pustaka Pelajar.

Kosasih, E. (2014). Dasar-Dasar Keterampilan Bersastra. Bandung: Yrama Widya.

Purwanti, D. (2017). Peningkatan Kemampuan Menulis Pantun dengan Menggunakan Model Berpikir Berbicara Menulis (Think Talk Write). Ciamis: Universitas Galuh

Sari, S.D. dan Wagiran. (2016). Peningkatan Keterampilan Menulis Teks Berita dengan Pemanfaatan Media Kliping Foto Jurnalistik pada Siswa Kelas VIII C SMP Negeri 8 Batang. Batang: Universitas Negeri Semarang. 
Shoimin, A. (2014). 68 Model Pembelajaran Inovatif dalam Kurikulum 2013. Yogyakarta: Ar-Ruzz Media.

Sugiyono. (2017). Metode Penelitian Pendidikan Pendekatan Kuantitatif, Kualitatif, dan $R \& D$. Bandung: Alfabeta.

Wardoyo, M. S. (2013). Teknik Menulis Puisi. Bndung: Graha Ilmu.

Wijaya, T. (2016). Photo Story Handbook Panduan Membuat Foto Cerita. Jakarta: Gramedia Pustaka Utama.

Yunus. (2009). Keterampilan Dasar Menulis. Jakarta: Universitas Terbuka.

Zainurrahman. (2013). Menulis dari Teori Hingga Praktis (Penawar Racun Plagiarisme). Bandung: Alfa Beta. 